\title{
Wykaz prac magisterskich napisanych na seminariach językoznawczych w Instytucie Filologii Polskiej UAM w roku akademickim 2011/2012
}

1. Aleksandra Adamczyk, Przezwiska uczniów i nauczycieli w Zespole Szkót im. Marii Curie-Skłodowskiej w Kętrzynie (prof. dr hab. Bogdan Walczak $^{1}$ ).

2. Konrad Adamski, Co ty wiesz o... cytowaniu? Cytaty i skrzydlate stowa z filmów funkcjonujace we wspótczesnej polszczyźnie (prof. dr hab. Anna Piotrowicz).

3. Aybaniz Aliyeva, Językowy obraz kobiety wiejskiej w powieści polskiej $i$ azerbejdżańskiej (na przyktadzie „Chłopów” Władystawa Stanistawa Reymonta oraz „Zniknięcia osta” Dżaliła Mammedgułuzadiego) (prof. dr hab. Alicja Pihan-Kijasowa).

4. Monika Araszczuk, Niestosowne imiona Polek i Polaków w opiniach Rady Języka Polskiego (prof. dr hab. Tadeusz Zgółka).

5. Marcin Bąbelek, Taktyki perswazji $i$ manipulacji $w$ tekstach internetowych banerów reklamowych (prof. dr hab. Tadeusz Zgółka).

${ }^{1} \mathrm{~W}$ nawiasach umieszczono nazwiska promotorów prac.
6. Aldona Błochowiak, Współczesna znajomość mowy mieszkańców Poznania i Wielkopolski na przyktadzie badanej zbiorowości (prof. dr hab. Bogdan Walczak).

7. Milena Czajka, Zjawisko kiczu językowego $w$ piosenkach disco-polo (prof. dr hab. Andrzej Sieradzki).

8. Karolina Czarnecka, Językowe oblicza komplementu. Studium pragmalingwistyczne (prof. dr hab. Tadeusz Zgółka).

9. Michał Czubak, Językowy obraz miasta $w$ prasie codziennej (na przyktadzie dziennika „Polska Gtos Wielkopolski”) (prof. dr hab. Anna Piotrowicz).

10. Dryjałska Jo anna, Stylizacja na język młodzieżowy w wybranych numerach czasopism: „Bravo”, „Bravo Girl!”, „Popcorn”, ,Dziewczyna” (prof. dr hab. Andrzej Sieradzki).

11. Emilia Drzazgowska, Miejsce jezyka prawa we współczesnej polszczyźnie (prof. dr hab. Bogdan Walczak).

12. Karolina Fibich,Zżycia wyrazówsłowa, które wracaja i słowa, które umarly (prof. hab. Anna Piotrowicz). 
13. Marlena Gajowiecka, Charakterystyka wybranych toponimów $i$ antroponimów $w$ gminie Janowiec Wielkopolski i okolicy (prof. dr hab. Bogdan Walczak).

14. Maria Grzebyta, Oblicza kłamstwa. Studium pragmalingwistyczne (prof. dr hab. Tadeusz Zgółka).

15. Paulina Heyer, Stereotyp księdza katolickiego (prof. dr hab. Tadeusz Zgółka).

16. Magdalena Jabłońska, Ironiczna $i$ sarkastyczna retoryka Janusza Korwina-Mikkego, czyli neosemantyzmy $i$ neologizmy uzywane $w$ jego felietonistyce (prof. dr hab. Tadeusz Zgółka).

17. Marta Jabłońska, Formacje deminutywne w powieściach Małgorzaty Musierowicz „,Szósta klepka” $i$,,Spręzyna" (prof. dr hab. Anna Piotrowicz).

18. Agata Jankowska, Językowy obraz konsumpcji i konsumenta $w$ tekstach hip-hopowych (prof. dr hab. Anna Piotrowicz).

19. Beata Jerzakowska, „Nasza mitość jest staba i głodna [...]". Analiza bloku epistolarnego Agnieszki Osieckiej i Jeremiego Przybory pt. „Listy na wyczerpanym papierze" (prof. dr hab. Stanisław Mikołajczak).

20. Anna Kaczmarek, Amerykanizacja polszczyzny $w$ polskich serialach obyczajowych (prof. dr hab. Anna Piotrowicz).

21. Małgorzata Kapuściak, Stownictwo kosmetyczne $w$ najnowszej polszczyźnie ogólnej (na przykładzie „Współczesnego stownika języka polskiego" pod red. Bogustawa Dunaja) (prof. dr hab. Anna Piotrowicz).

22. Nastassia Kharak, Nazwy dni, miesięcy i pór roku $w$ wybranych językach naturalnych $i$ pomocniczych (prof. dr hab. Bogdan Walczak).
23. Anna Kliber, Biolekt, czyli język płci-teoria a praktyka (prof. dr hab. Andrzej Sieradzki).

24. Anna Kołcon, Komizm w różnych odstonach $w$ oparciu o teksty kabaretu Tey. Analiza językowo-stylistyczna (prof. dr hab. Stanisław Mikołajczak).

25. Ida Konovalik, Gwara studentów polskich $i$ rosyjskich (studium porównawcze) (prof. dr hab. Andrzej Sieradzki).

26. Paulina Kopajczyk, Analiza błędów popetnionych przez stuchaczy kursów języka polskiego jako obcego (w Studium Języka i Kultury Polskiej dla Cudzoziemców UAM) (prof. dr hab. Bogdan Walczak).

27. Joanna Korczak, Stownictwo ekspresywne w gwarze miejskiej Poznania (na podstawie „Stownika gwary miejskiej Poznania" pod red. Moniki Gruchmanowej i Bogdana Walczaka) (prof. dr hab. Anna Piotrowicz).

28. Katarzyna Koronkowska, Językowe środki kreowania wizerunku w blogach osób publicznych (prof. dr hab. Anna Piotrowicz).

29. Karina Koś, Inskrypcja nagrobna jako komunikat językowy (prof. dr hab. Andrzej Sieradzki).

30. Dagmara Kotulsk a, Jak rozpoczynamy $i$ kończymy listy pisane $w$ Sieci (prof. dr hab. Tadeusz Zgółka).

31. Agnieszka Kowal, Prowokacja jako swoistość języka religijnego Szymona Hołowni (prof. dr hab. Stanisław Mikołajczak).

32. Katarzyna Kowalczyk, Wybrane przyimki przestrzennodynamiczne taczace się z czasownikami ruchu w języku serbskim i polskim (prof. dr hab. Andrzej Sieradzki).

33. Anna Kowerska, Analiza językowa tytułów rozdziatów $i$ artykułów 
w Kodeksie karnym (prof. dr hab. Tadeusz Zgółka).

34. Anna Krajewska, Terminologia muzyczna $w$ słownikach języka polskiego i wyrazów obcych (na przykładzie ,Uniwersalnego stownika języka polskiego" pod redakcja Stanistawa Dubisza $i$,,Wielkiego stownika wyrazów obcych" pod redakcja Mirosława Bańki) (prof. dr hab. Anna Piotrowicz).

35. Małgorzata Krawczykowska, Rozwój mowy dziecka w wieku przedszkolnym (prof. dr hab. Andrzej Sieradzki).

36. Ewelina Krzempek, Etykieta językowa $w$,Nad Niemnem” Elizy Orzeszkowej (prof. dr hab. Anna Piotrowicz).

37. Aleksandra Macionga, Gry językowe w SMS-ach widzów ,Szkła kontaktowego" (prof. dr hab. Anna Piotrowicz).

38. Zuzanna Majewicz, Wartości w powiastkach homiletycznych. Medytacje semantyczne (prof. dr hab. Tadeusz Zgółka).

39. Anna Malisz, Konceptualizacja pojęć feminizm i feministka przez uczniów szkót średnich (prof. dr hab. Andrzej Sieradzki).

40. Iwona Maliszewska, Zapożyczenia angielskie we wspótczesnym stownictwie kosmetycznym (prof. $\mathrm{dr}$ hab. Anna Piotrowicz).

41. Joanna Matusiak, Polszczyzna konsumpcyjna $w$ branży samochodowej (prof. dr hab. Anna Piotrowicz).

42. Adrianna Mielnik, Poziom wulgaryzacji wśród studentów poznańskich uczelni wyższych (prof. dr hab. Tadeusz Zgółka).

43. Noemi Nowak, Perswazja wartościujaca $w$ prasowych sloganach reklamowych na przykładzie tygodnika
„Polityka” (prof. dr hab. Tadeusz Zgółka).

44. Katarzyna Odważna, Stowami wyrażony świat kobiecy Zofii Nałkowskiej (prof. dr hab. Tadeusz Zgółka).

45. Helena Paździoch, Charakterystyka gwary ochweśnickiej (prof. dr hab. Anna Piotrowicz).

46. Marta Pokorska, Wulgaryzacja polszczyzny w powieści ,Oficer” Tadeusza Siejaka (prof. dr hab. Anna Piotrowicz).

47. Anna Przybylska, Stowami wyrażony świat zespołu Maanam. Studium leksykologiczne (prof. dr hab. Tadeusz Zgółka).

48. Karolina Raźna, Język hip-hopu (wybrane zagadnienia) (prof. dr hab. Andrzej Sieradzki).

49. Anna Rorat, Językowy obraz świata $w$ czasopismach motocyklowych (prof. dr hab. Stanisław Mikołajczak).

50. Anna Sabik, Dyskurs mody w czasopiśmie „Dziewczyna” (prof. $\mathrm{dr}$ hab. Andrzej Sieradzki).

51. Assel Sagimbekova, Obraz kobiety $w$ przystowiach $i$ antroponimach. Studium porównawcze na materiale języka polskiego $i \mathrm{ka}$ zachskiego (prof. dr hab. Bogdan Walczak).

52. Ewelina Siemion,Nazwiska mieszkańców parafii Kleczkowo z XVII $i$ XVIII wieku (prof. dr hab. Stanisław Mikołajczak).

53. Karolina Sobol, Formacje deminutywne $w$,Innym stowniku języka polskiego" pod redakcja Mirostawa Bańki. Kwalifikatory, definicje, pragmatyka (prof. dr hab. Anna Piotrowicz).

54. Ewa Szakoła, Świat przedstawio$n y$ w tekstach wykonywanych przez zespót Dżem. Analiza słownictwa au- 
tosemantycznego (prof. dr hab. Tadeusz Zgółka).

55. Michał Szott, Etyka dziennikarska a język dziennikarzy (prof. dr hab. Stanisław Mikołajczak).

56. Beata Walczak, Językowe środki perswazji w reklamach telewizyjnych (prof. dr hab. Andrzej Sieradzki).

57. Karolina Werstler, Komunikacja językowa $w$ środowisku pitkarskim (prof. dr hab. Anna Piotrowicz).

58. Karolina Winiecka, Specyfika prasy lokalnej na przykładzie „, Gazety Ostrowskiej” $i$,, Kuriera Ostrowskiego" (prof. dr hab. Andrzej Sieradzki).

59. Aleksandra Wojciechowska, Konflikty matżenskie - aspekt komunikacyjny (poziom teoretyczny $i$ praktyczny) (prof. dr hab. Andrzej Sieradzki).
60. Alina Wojciechowska, Frazeologizmy w powieści Matgorzaty Musierowicz „Kłamczucha” (prof. dr hab. Anna Piotrowicz).

61. Monika Wolska, Środki leksykalne charakterystyczne dla wypowiedzi politycznych Stefana Niesiołowskiego (prof. dr hab. Tadeusz Zgółka).

62. Małgorzata Zakrzewska, Leksyka wojenna $w$ reportażu Wojciecha Jagielskiego „, Wieże z kamienia” (prof. dr hab. Anna Piotrowicz).

63. Jarosław Żarski, Nazwy handlowe polskich wódek $w$ opinii przeciętnego konsumenta. Studium pragmalingwistyczne (prof. dr hab. Tadeusz Zgółka).

Sporządziła

Agnieszka Krygier-Łaczkowska 